IFAS Extension

\title{
A Colonial Tentweb Orbweaver Cyrtophora citricola ${ }^{1}$
}

\author{
Lionel A. Stange ${ }^{2}$
}

\section{Introduction}

Few species of spiders can be considered truly social, but more species, particularly web-building spiders, live in close proximity to one another, potentially gaining benefits by this association. Among these benefits are sharing of frame threads (Kullman 1959), improved defense against predators and parasites (Cangialosi 1990), improved prey capture efficiency (Rypstra 1979; Uetz 1989), and greater egg production (Smith 1983).

Of the three main types of aggregative behaviors exhibited by spiders, the one with the least social interaction involves individuals making and maintaining their own webs within a colonial matrix of interconnected webs (Buskirk 1975). One such species, which has become highly successful through a lifestyle of colonial aggregation, is the orbweaver Cyrtophora citricola Forskål. This species is known as a tentweb spider in Africa (Dippenaar-Schoeman and Jocqué 1997). In 2000, this species was found in southern Florida in Miami-Dade County. The first localities where the species was discovered were: 20700 SW 167 Ave, 8 March 2000, one juvenile (Duraid Hanna, DPI Inspector \#322; sample \#2000-545), and at the same locale, 12 April 2000, one female, one juvenile (Julieta Brambila, DPI Technician; sample \#2000-965); junction Silver Palm Rd (= SW 232 St) and Old Dixie Hwy, 9 May 2000, two males (Julieta Brambila, DPI; sample \#2000-1337); Fruit and Spice Park, 24801 SW 187 Ave, 9 August 2000, one female, one juvenile, two eggsacs (Julieta Brambila, DPI; sample \#2000-2597). All of these locales are north of Homestead. The first published report (Halbert 2000) listed the first two records above. Initial spread of this species was reported by Mannion et al. (2002).

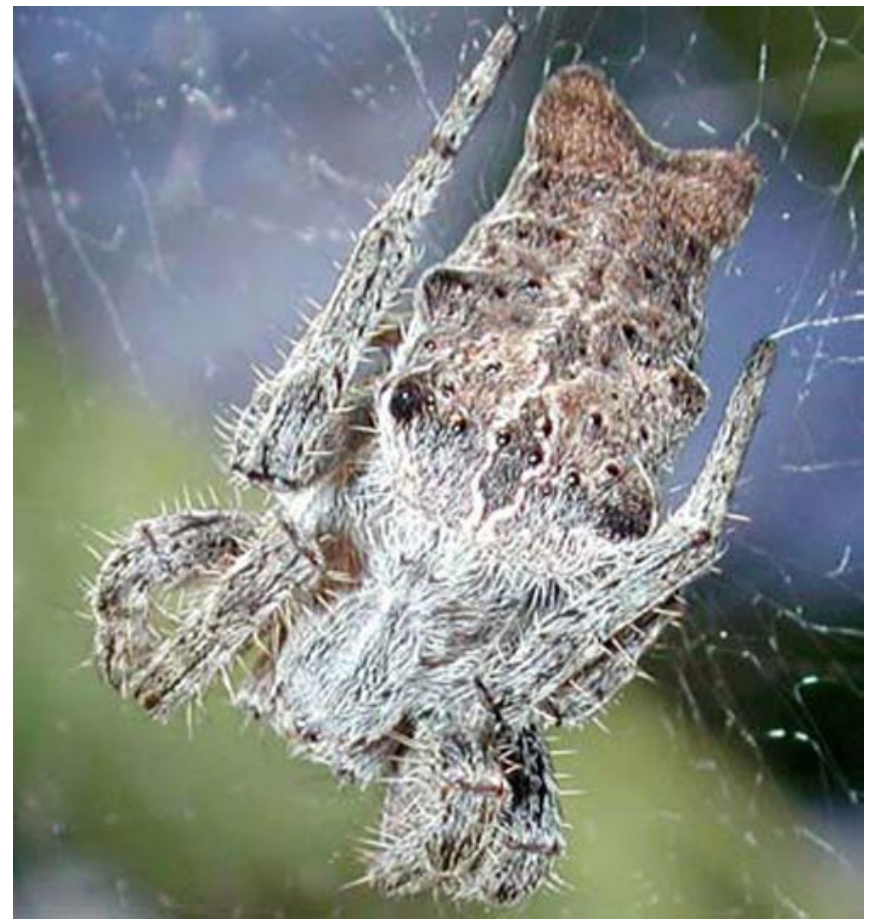

Figure 1. Cyrtophora citricola female in cryptic resting pose, showing details of color pattern

Credits: Ian McGuire, Division of Plant Industry, Florida Department of Agriculture and Consumer Services.

1. This document is EENY-535, one of a series of the Entomology and Nematology Department, Florida Cooperative Extension Service, Institute of Food and Agricultural Sciences, University of Florida. Original publication date October 2012. Revised April 2013. This document is also available as a Featured Creature at http://entomology.ifas.ufl.edu/creatures. Visit the EDIS website at http://edis.ifas.ufl.edu.

2. Lionel A. Stange, Florida Department of Agriculture \& Consumer Services, Division of Plant Industry, Gainesville, FL 32611. Originally published as DPI Entomology Circular No. 411. 


\section{Distribution}

Cyrtophora citricola is widespread in subtropical and tropical areas of Asia, Africa, Australia, and in the warm coastal Mediterranean areas of Europe (Blanke 1972; Leborgne et al. 1998). Recently, it has been found in Colombia in 1996 (Levi 1997; Pulido 2002), the Dominican Republic in 1999 (Alayón 2001), Florida in 2000, and Cuba in 2003 (Alayón 2003). I conducted survey work in August 2000, April 2001, and July 2002 to document the spread of the species in Florida. I was facilitated greatly in this effort by a tendency for Cyrtophora citricola to make its webs on the guardrails of canal bridges (Fig. 6). I obtained a map of the canals (South Florida Water Management District, Miami-Dade County Canal Maintenance, Water Resources Operations, revised 7/6/00) with associated roads and bridges. Beginning at the sites recorded above as the core area, I examined bridges away from the core area in all directions. I also looked for telltale webbing on trees and bushes as I drove from bridge to bridge.

The survey work in 2000 established a preliminary periphery of infestation in a narrow band from west of Homestead to northeast of Homestead. Outer boundaries were SW 217 Ave at canal C-113 to the southwest, SW 217 Ave at C-103 to the northwest, SW 320 St at C-103S in Homestead to the southeast, and from there on a diagonal line northeast to SW 232 St at C-1. Some gaps existed in this distribution, most noticeably on canal C-103N where I did not find Cyrtophora citricola at that time.

The second survey in 2001 mostly filled the gaps, especially on C-103N, extended the distribution eastward to SW 117 Ave at C-103 and SW 107 Ave at Military Canal, and northward to SW 177 Ave at C-102, SW 184 St at C-1, and SW 145 St at C100A.

The third survey in 2002 filled other gaps, and extended the distribution northward to SW 177 Ave at C-1W and SW 135 St at C-100C. A record from nearby Fairchild Botanical Gardens to the east was also reported [18 April 2002, one female (Richard Campbell, FBG, DPI sample; \#2002-1296)].

To date, the known distribution of Cyrtophora citricola in Florida is a parallelogram-shaped area from east of the Everglades National Park to the east coast of Florida, bounded on the south by a latitudinal line extending through Homestead, and on the north by a similar line extending through Pinecrest and Coral Gables.

\section{Identification}

Adult female spiders average just over $10 \mathrm{~mm}$ in body length and are fairly robust. Males are very small, averaging about $3 \mathrm{~mm}$ in length (Levi 1997). Genitalic details are used to distinguish this species from congeners in other parts of the world. Females and males are typically medium brown in color, but may have a darker foliate mark on the dorsum of the abdomen. Both can change the background color of the abdomen from very pale to very dark (Blanke 1972). Florida males often appear black, whereas females vary considerably in overall appearance. Females (Figs. 1 and 2), despite their larger size, are very cryptic in color and shape, and sometimes hard to see in the web. They resemble a piece of dead leaf, and may sometimes hide on dead leaves that have fallen into the web. A characteristic of the species that will distinguish it from all other genera in Florida, except Allocyclosa (which has a much smaller female; Levi 1999), is the horizontally oriented bifurcation at the posterior of the abdomen.

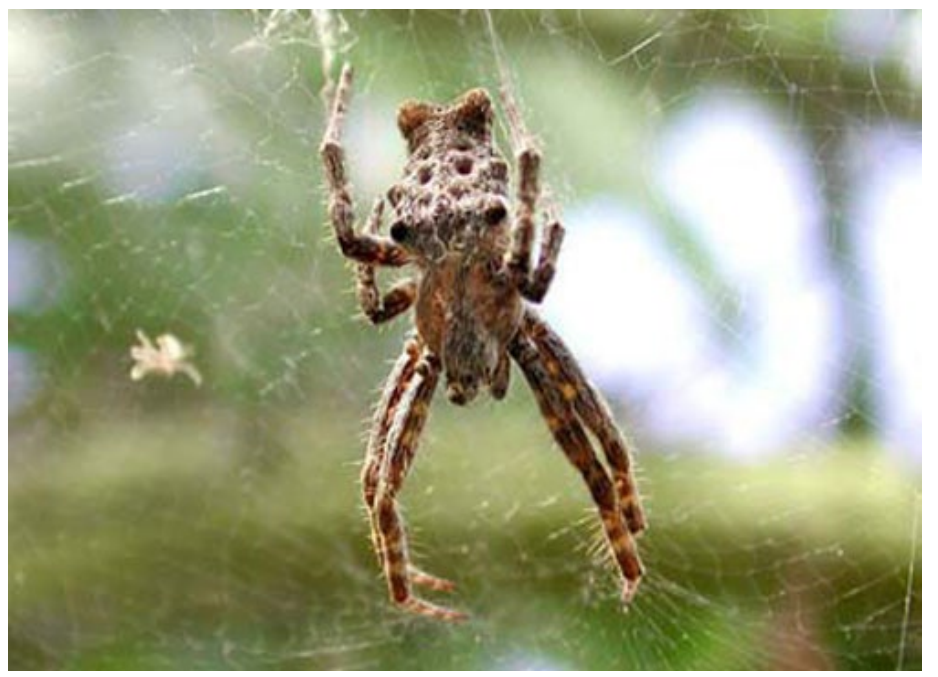

Figure 2. Female Cyrtophora citricola in web-monitoring pose. Credits: Ian McGuire, Division of Plant Industry, Florida Department of Agriculture and Consumer Services.

\section{Biology}

Some extensive studies have been conducted on the biology of Cyrtophora citricola, including those from Andalusia (Blanke 1972), Sardinia (Kullman 1958, 1959), Sicily (Leborgne et al. 1998), Gabon (Rypstra 1979), and Colombia (Suárez 1998). Blanke (1972) found that Cyrtophora citricola could not survive when temperatures fell below $-1{ }^{\circ} \mathrm{C}$. This species is known to have a lifestyle that varies from existing as solitary individuals to occurring in large colonies of hundreds of individuals (Leborgne et al. 1998). A prerequisite for a colonial existence might be a certain amount of tolerance for conspecifics and is exhibited by 
Cyrtophora citricola when encountering other individuals on common threads. However, when the personal preycapture web is invaded by another spider, Cyrtophora individuals will exhibit aggressive behavior (Kullman 1959; Lubin 1974).

These spiders build a horizontal orb web that has a dense vertical barrier of silk strands above the orb, and a less dense barrier below it. Individuals hang underneath the middle of their own orb web and catch insects that are intercepted by the upper barrier, from which they fall onto the orb. The webs are non-adhesive, so the silk acts only as a temporary restraining device. This is a less efficient web than those that have sticky spirals, so living in an aggregation of webs is advantageous by potentially increasing the number of prey that hit the web (Rypstra 1979; Uetz 1989). Leborgne et al. (1998) found that spiders that lived in colonies had smaller webs than those that were solitary, but they caught an equal amount and size of prey as solitary individuals; therefore, it appeared that the colonial webs were indeed more efficient.

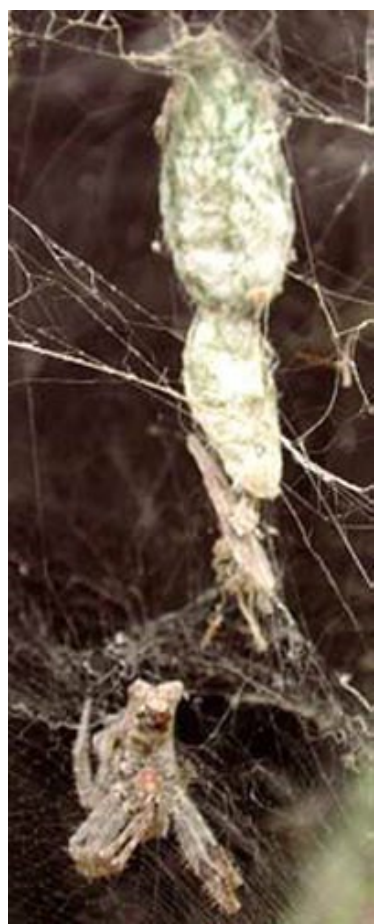

Figure 3. Female Cyrtophora citricola with two eggsacs.

Credits: Ian McGuire, Division of Plant Industry, Florida Department of Agriculture and Consumer Services.

Eggsacs (Fig. 3) have a flattened, elliptical shape, about $12-20 \mathrm{~mm}$ in greatest diameter, and have a bluish or greenish tinge. They are laid in a long chain of up to 10 eggsacs above the web. The newest eggsacs are closest to the web. Eggsacs average 112-157 eggs depending on the year's productivity and lifestyle (colonial or solitary) of the mother (Leborgne et al. 1998). Colonies in Florida appear to form around a single female, with the young attaching their webs to the mother's web rather than dispersing. Colonies can be eventually several square meters in area and cover entire trees (e.g., of Citrus spp.).

Other spider species can be found associated with Cyrtophora citricola colonies. Some are other orbweaving spiders that use the framework and benefit from other advantages provided by these aggregations. In Florida, such species include Mecynogea lemniscata (Walckenaer), Metepeira labyrinthea (Hentz), and Nephila clavipes (L.). Several kleptoparasitic species of Argyrodes also have been found in these colonies. Elsewhere (Leborgne et al. 1998), Cyrtophora citricola colonies are victimized by Argyrodes argyrodes (Walckenaer) [sub A. gibbosus (Lucas)], which steal prey and eat unguarded Cyrtophora eggs, and by pholcid spiders [Holocnemus pluchei (Scopoli)], which use the colony communal network to attach their own webs, and they attack juveniles and adults of Cyrtophora citricola (Blanke 1972; Leborgne et al. 1998). Leborgne et al. (1998) reported that another benefit for Cyrtophora citricola living in a colony was a lower number of kleptoparasitic spiders per web in colonies vs. solitary webs, although Rypstra (1979) noted that larger colonies attracted more predators and kleptoparasites. When attacked, Cyrtophora citricola will drop several centimeters on a dragline and resume a cryptic pose, or drop to the ground where its color blends in with the soil and litter, or retreat to a sheltered area if available, where it will attempt to hide (e.g., behind a guard rail post).

\section{Hosts}

The following plants cannot be considered true hosts, as the spiders do not feed on them. However, these plants have been documented as being used for web attachment (Figs. 4 and 5); therefore, they are subject to potential damage by heavy spider populations. Florida hosts include akee, Blighia sapida K. Koenig; Australian brush-cherry, Syzygium paniculatum Gaertn.; balsam apple, Clusia rosea Jacq.; Barbados cherry, Malpighia glabra L.; beggarticks, Bidens sp.; citrus, Citrus sp.; gardenia, Gardenia augusta (L.) Merr.; grapefruit, Citrus x paradisi Macfad.; a hedge plant, Eugenia coronata Schumach. \& Thonn.; lime, Citrus aurantifolia (Christm.) Swingle; mamey sapote, Pouteria sapota (Jacq.) H. E. Moore \& Stearn; mango, Mangifera indica L.; orange, Citrus sinensis (L.) Osbeck; pygmy date palm, Phoenix roebelenii O'Brien; sausage tree, Kigelia africana (Lam.) Benth.; and weeping fig, Ficus benjamina L. Hosts documented in 
Colombia (Pulido 2002) include acacia, Acacia sp.; almond, Prunus dulcis (Mill.) D. A. Webb; araucaria, Araucaria sp.; banana, Musa acuminata Colla; cacao, Theobroma cacao L.; caucho, Clusia sp.; cedro (Spanish cedar), Cedrela odorata L.; chiminango, Pithecellobium dulce (Roxb.) Benth.; eucalyptus, Eucalyptus sp.; ficus, Ficus sp.; fique, Agave sp.; guanábana, Annona muricata L.; guava, Psidium guajava L.; lemon, Citrus limon (L.) Burm. f.; madroño, Garcinia madruno (kunth) B. Hammell.; mango, Mangifera indica L.; maracuyá (passion fruit), Passiflora sp.; matarraton, Gliricidia sepium (Jacq.) Kunth ex Walp.; orange, Citrus sinensis (L.) Osbeck; plantain, Musa x paradisiaca L.; swinglea, Swinglea glutinosa (Blanco) Merr.; totumo (calabash), Crescentia cujete L.; veranera, Bougainvillea sp.; and yuca, Manihot esculenta Crantz. Coffee, Coffea arabica L. (Cárdenas-Murillo et al. 1997), also has been reported from Colombia as a substrate for Cyrtophora citricola. It is likely that any plant providing the appropriate substrate to support a web framework could be colonized.

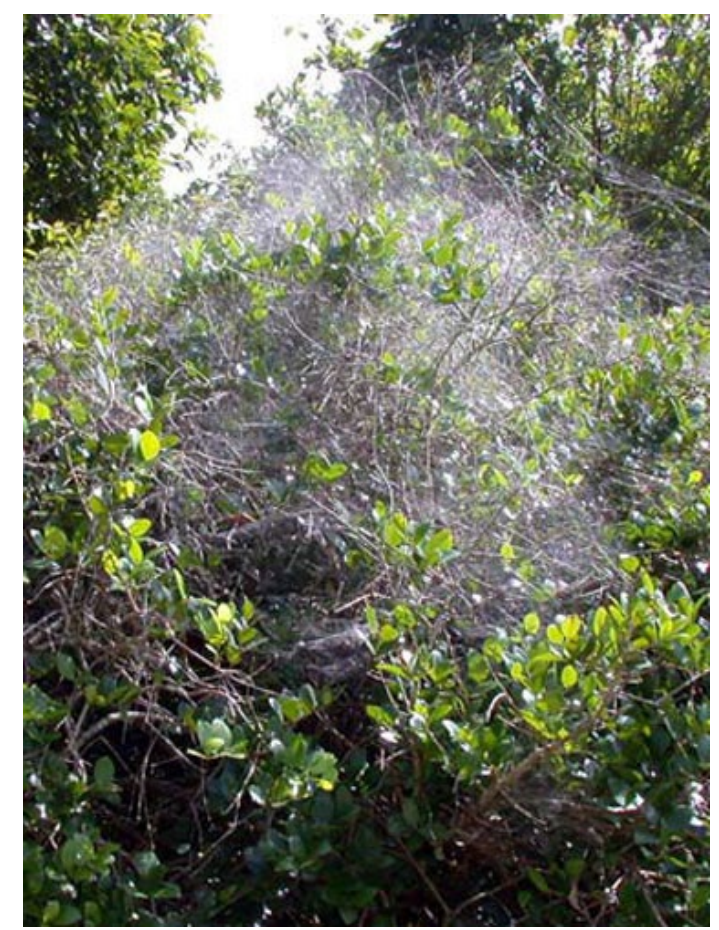

Figure 4. Extensive covering of Cyrtophora citricola webbing on upper half of Eugenia coronata.

Credits: G.B. Edwards, Division of Plant Industry, Florida Department of Agriculture and Consumer Services.

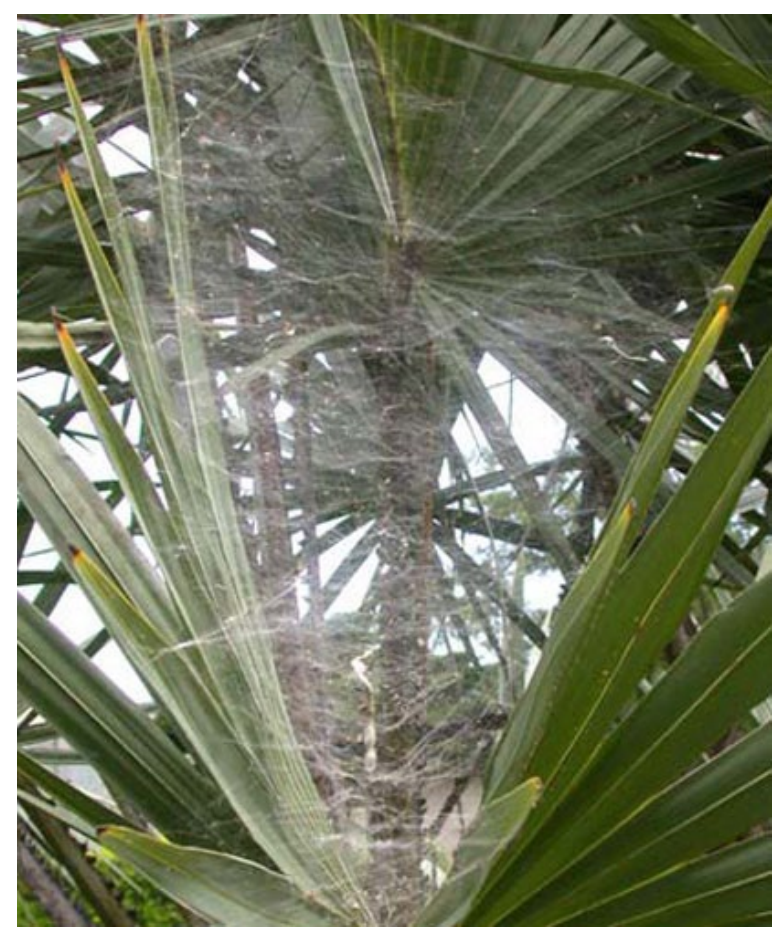

Figure 5. Colony of Cyrtophora citricola filling space between palm leaves.

Credits: G.B. Edwards, Division of Plant Industry, Florida Department of Agriculture and Consumer Services.

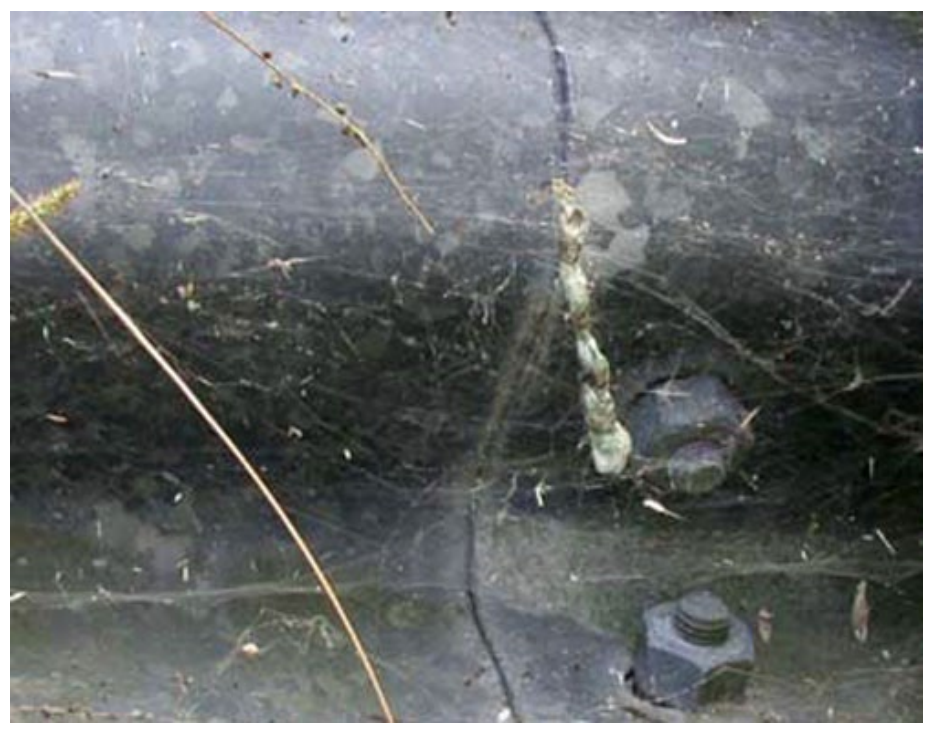

Figure 6. Colony of Cyrtophora citricola on guardrail of canal bridge. Note the string of five eggsacs in the right middle of the picture, just above a horizontal web.

Credits: G.B. Edwards, Division of Plant Industry, Florida Department of Agriculture and Consumer Services.

\section{Economic Importance}

Possibly, Cyrtophora citricola is both beneficial and deleterious. Undoubtedly, the cover of webs on a plant would capture pest insects associated with that plant. However, multiple observations have been reported of leaf loss (Fig. 
7), terminal twig dieback (Fig. 8), and sometimes plant death, allegedly due to asphyxiation of the plant, where heavy populations of this spider have become established (Levi 1997). It has been proposed that the extensive web cover absorbs the sun's radiation and raises the temperature, causing the leaves and young fruit to desiccate (CárdenasMurillo et al. 1997). This seems unlikely per se, as the white silk would seem to reflect sunlight rather than absorb it. A suggestion worth investigating is that the density of the webbing might restrict air flow over the leaves, with the same result of raising the temperature (Richard Weaver, personal communication 2003). Palms seem to be resistant to the damage caused to plants with small leaves.

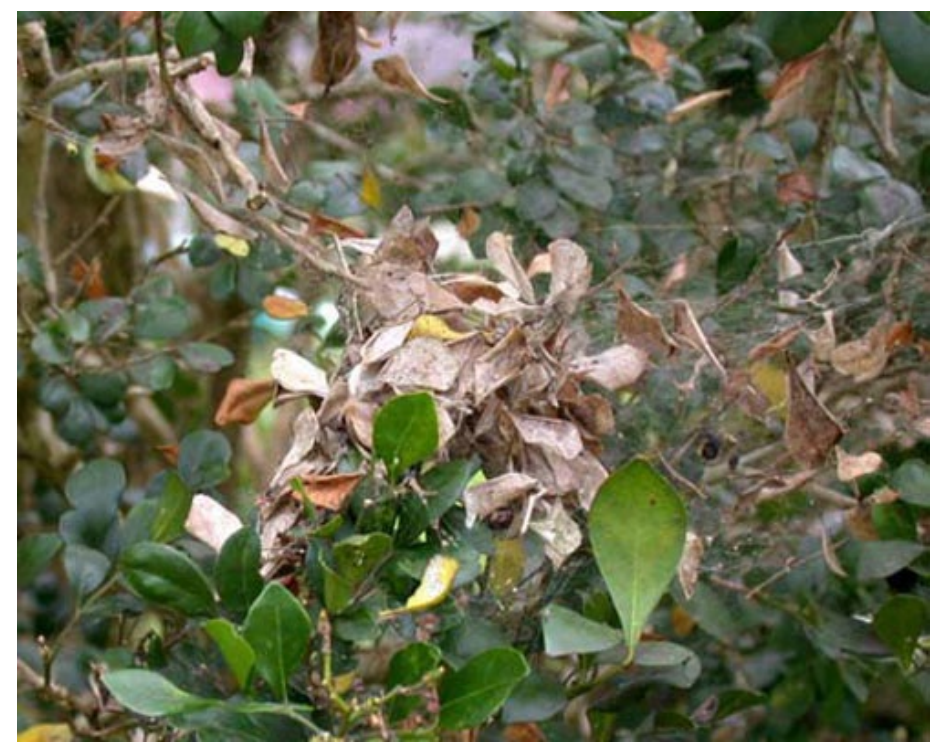

Figure 7. Dead leaves accumulated in Cyrtophora citricola webbing on Eugenia coronata.

Credits: G.B. Edwards, Division of Plant Industry, Florida Department of Agriculture and Consumer Services.

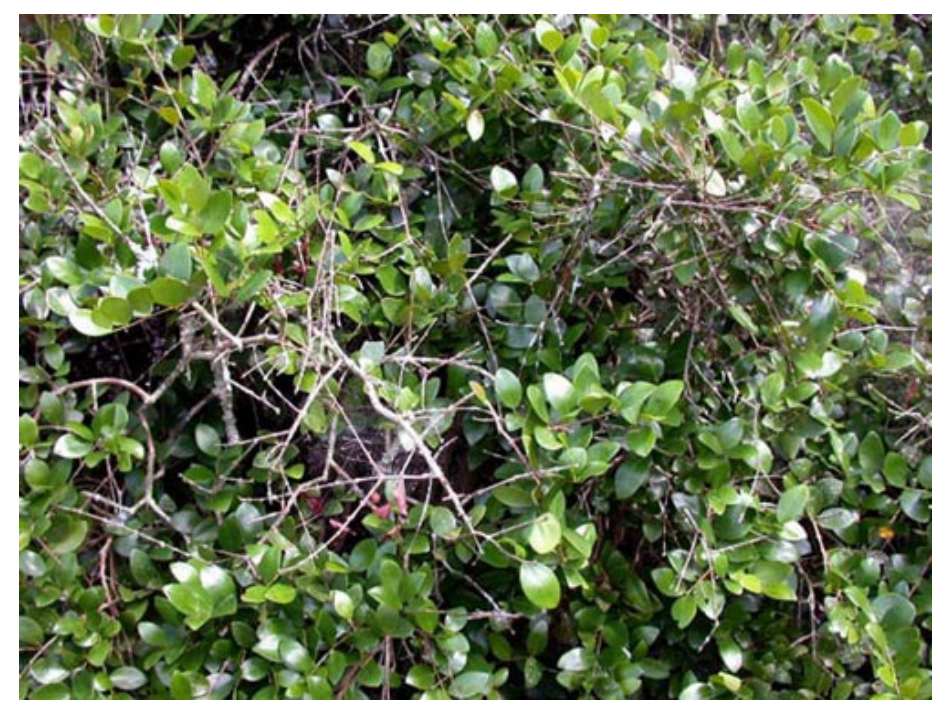

Figure 8. Multiple dead twigs due to Cyrtophora citricola webbing on Eugenia coronata.

Credits: G.B. Edwards, Division of Plant Industry, Florida Department of Agriculture and Consumer Services.

\section{Control}

Mechanical control is recommended on a small scale (Pulido 2002). Chemical controls will depend on labeling for the type of plant and for spiders. Because of the amount of debris that accumulates in affected plants, chemical control is likely to be unreliable because of incomplete coverage. While this might be overcome by high pressure sprayers, pressure spraying using only water was found to facilitate dispersal of the spiders (Pulido 2002).

\section{Acknowledgements}

I thank Julieta Brambila, José Diaz, Luz Lastra, and Dr. Richard Weaver, all Division of Plant Industry, and Dr. Catherine Mannion, University of Florida, Tropical Research and Education Center, Homestead, for various types of assistance on this publication.

\section{Selected References}

Alayón GG. 2001. Presencia de Cyrtophora citricola (Forskal, 1775) (Araneae: Araneidae) in las Antilles. Revista Ibérica de Arachnología 4: 9-10.

Alayón GG. 2003. Cyrtophora citricola (Araneae: Araneidae), registro neuvo de araña para Cuba. Cocuyo 13: 14.

Blanke R. 1972. Field studies on the ecology and ethology of Cyrtophora citricola Araneidae in Andalusia. Forma et Funcio 5(2): 125-206.

Buskirk RE. 1975. Coloniality, activity patterns and feeding in a tropical orb-weaving spider. Ecology 56: 1314-1328.

Cangialosi KR. 1990. Social spider defense against kleptoparasitism. Behavioral Ecology and Sociobiology 27: 49-54.

Cárdenas-Murillo R, Posada-Flórez FJ, Bustillo-Pardey AE. 1997. Daños causados por arañas en los cafetales. Federación Nacional de Cafeteros de Colombia, Cenicafé Avances Técnicos 242. 4 p.

Dippenaar-Schoeman AS, Jocqué R. 1997. African Spiders, an Identification Manual. Plant Protection Research Institute Handbook No. 9. Biosystematics Division, ARCPlant Protection Research Institute, Pretoria, South Africa. $392 \mathrm{p}$.

Halbert SE. 2000. Arthropod Detection. Florida Department of Agriculture and Consumer Services, Division of Plant Industry, Tri-ology 39(2): 7. 
Kullman E. 1958. Beobachtung des Netzbaues und Beiträge zur Biologie von Cyrtophora citricola Forskal (Araneae, Araneidae). Zoologische Jahrbücher Abteilung für Systematik, Ökologie und Geographie der Tiere 86(3): 181-216.

Kullman E. 1959. Beobachtungen an der Raumnetzspinne Cyrtophora citricola Forskal auf Sardinien (Araneae, Araneidae). Deutsche Entomologische Zeitschrift 6 III: 65-80.

Leborgne R, Cantarella T, Pasquet A. 1998. Colonial life versus solitary life in Cyrtophora citricola (Araneae, Araneidae). Insectes Sociaux 45: 125-134.

Levi HW. 1997. The American orb weavers of the genera Mecynogea, Manogea, Kapogea, and Cyrtophora (Araneae: Araneidae). Bulletin of the Museum of Comparative Zoology 155(5): 215-255.

Levi HW. 1999. The Neotropical and Mexican orb weavers of the genera Cyclosa and Allocyclosa (Araneae: Araneidae). Bulletin of the Museum of Comparative Zoology 155(7): 299-379.

Lubin YD. 1974. Adaptative advantages and the evolution of colony formation in Cyrtophora (Araneae, Araneidae). Zoological Journal of the Linnean Society 54: 321-339.

Mannion C, Amalin D, Peña J, Edwards GB. 2002. A new spider in Miami-Dade County: Cyrtophora citricola. University of Florida Extension, Horticultural Newsletter 2(2): 3 .

Pulido FJI. 2002. Manejo de la araña del Mediterraneo o araña parda enredadora. Instituto Colombiano Agropecuario report. 5p.

Rypstra AL. 1979. Foraging flocks of spiders. A study of aggregate behaviour in Cyrtophora citricola Forskål (Araneae: Araneidae) in West Africa. Behavioral Ecology and Sociobiology 5: 291-300.

Smith D. 1983. Ecological costs and benefits of communal behavior in a presocial spider. Behavioral Ecology and Sociobiolog13:107-114.

Suárez OYS. 1998. Identificación taxonómica, observación sobre la biología y comportamiento de Cyrtophora citricola Forskal (Arachnida: Araneidae). Universidad Nacional de Colombia, Agronomy Engineer thesis. 49 p.
Uetz GW. 1989. The "ricochet effect" and prey capture in colonial spiders. Oecologia 81:154-159. 